\title{
Skrining Fitokimia dan Evaluasi Sediaan Sabun Cair Ekstrak Etanol 96\% Kulit Buah Salak Pondoh (Salacca zalacca (Gaertn.) Voss.) Sebagai Antioksidan
}

\author{
Andi Nafisah Tendri Adjeng ${ }^{*}$, Sania Hairah ${ }^{2}$, Syahlan Herman ${ }^{2}$, Ruslin ${ }^{1}$, La Ode Muhammad \\ Fitrawan $^{1}$, Ari Sartinah ${ }^{1}$, Nur Fitriana Muhammad Ali ${ }^{2}$, Sabarudin ${ }^{1}$
}

\footnotetext{
1) Fakultas Farmasi Universitas Halu Oleo, Kampus Hijau Bumi Tridharma Anduonohu, Jl. H. E. A. Mokodompit Kendari 93232

2) Jurusan Farmasi Fakultas Sains dan Teknologi, Institut Teknologi dan Kesehatan Avicenna, Jl. Y. Wayong Kendari 93116
}

E-mail:nafisahandi23@gmail.com

\begin{abstract}
Abstrak
Pemanfaatan kulit buah Salacca zalacca (Gaertn.) Voss.) sebagai sumber antioksidan alami dalam sediaan sabun cair merupakan salah satu cara untuk mencegah efek buruk radikal bebas terhadap kesehatan kulit. Tujuan penelitian ini adalah melakukan skrining fitokimia terhadap senyawa metabolit sekunder yang terdapat dalam ekstrak etanol 96\% kulit buah Salacca zalacca (Gaertn.) Voss.) dan memformulasi serta mengevaluasi sediaan sabun cair dari ekstrak tersebut. Skrining fitokimia ekstrak dilakukan dengan menggunakan metode tabung. Penentuan variabel evaluasi sediaan sabun cair meliputi uji organoleptik, uji pH, tinggi busa dan viskositas. Hasil penelitian menunjukkan bahwa ekstrak etanol 96\% kulit buah Salacca zalacca (Gaertn.) Voss.) mengandung Flavonoid, Saponin, Tanin, dan Alkaloid. Sediaan sabun cair memilki karakteristik yaitu konsistensi yang cair, berwarna kuning kecoklatan, aroma rose. Tingkat keasaman $(\mathrm{pH})$ adalah 10,46 dengan viskositas adalah $600 \mathrm{cPs}$ dan Kestabilan busa mencapai 85\% dimana semua hasil evaluasi karakteristik sediaan sabun cair ekstrak Salacca zalacca (Gaertn.) Voss.) sesuai dengan parameter Standar Nasional Indonesia (SNI)
\end{abstract}

Kata kunci: ekstrak, etanol, sabun, Salacca zalacca, antioksidan

\section{Pendahuluan}

Radikal bebas berlebih dapat mengakibatkan efek buruk pada tubuh salah satunya yaitu terjadi kerusakan kulit [1]. Kerusakan kulit ditandai dengan adanya keriput, kulit bersisik, kering, dan pecah pecah. Sehingga diperlukan antioksidan untuk mengurangi dampak negatif dari radikal bebas [2]. Salak pondoh (Salacca zalacca (Gaertn.) Voss.) merupakan salah satu buah asli Indonesia yang berpotensi untuk dikembangkan sebagai antioksidan alami [3]. Salah satu bagian tanaman tersebut yaitu kulit buah salak, yang biasanya dibuang dan dianggap tidak bermanfaat, dari hasil penelitian menunjukkan ekstrak etanol dari kulit buah salak mempunyai aktivitas antioksidan yang kuat dengan nilai $\mathrm{IC}_{50}$ sebesar $99.1 \mathrm{ppm}$ $(\mu \mathrm{g} / \mathrm{mL})[4]$.

Berdasarkan khasiat dari kulit salak pondoh sebagai antioksidan, maka perlu dilakukan penelitian dengan memanfaatkan ekstrak kulit buah salak pondoh untuk mengembangkan suatu sediaan farmasi yang sering digunakan dikulit salah satunya adalah sabun. Bentuk sabun tidak hanya berupa padatan, tetapi sabun juga memiliki bentuk dengan konsistensi yang cair. Sabun bentuk cair saat ini banyak diproduksi karena penggunaannya yang lebih praktis dan bentuk yang lebih menarik dibanding bentuk sabun lain. Proses pembuatan sabun cair juga relatif lebih mudah dibandingkan proses pembuatan sabun padat [5].
Penelitian ini bertujuan untuk melakukan skrining fitokimia terhadap ekstrak etanol 96\% Salak (Salacca zalacca (Gaertn.) Voss.)) sehingga dapat diketahui senyawa matabolit sekunder yang terdapat dalam ekstrak tersebut, serta memformulasikan ekstrak tersebut dalam sediaan sabun cair dan melakukan evaluasi terhadap sediaan yang dihasilkan.

\section{Metode}

\subsection{Penyiapan Sampel dan Ekstraksi}

Sampel kulit buah salak pondoh diambil dari Desa Silea, Kecamatan Onembute, Kabupaten Konawe, Sulawesi Tenggara. Kulit buah yang diambil dari buah matang dan masih segar, kemudian dikeringkan anginkan dibawah sinar matahari dengan ditutupi kain hitam. Sebanyak 500 gram simplisia kulit salak yang telah dikeringkan, diserbukkan, lalu diekstraksi dengan metode maserasi menggunakan pelarut etanol $96 \%$ sebanyak 2 liter selama 3 hari. Dalam proses maserasi, dilakukan pengadukan sesekali dan dilakukan penggantian larutan penyari (etanol 96\%) setiap 1x24 jam. Maserat yang diperoleh kemudian disaring, lalu dipekatkan dengan menggunakan rotary vacuum evaporator pada suhu $55^{\circ} \mathrm{C}$ dan sampai didapatkan ekstrak kental. 


\subsection{Skrining Fitokimia}

\section{Uji Alkaloid}

Sebanyak $1 \mathrm{~mL}$ ekstrak dimasukkan ke dalam tabung reaksi kemudian ditambahkan 3 tetes pereaksi dragendorff. jika terbentuk endapan berwarna jingga atau merah bata, maka ekstrak positif mengandung alkaloid [6].

\section{Uji Flavonoid}

Sebanyak $1 \mathrm{~mL}$ ekstrak dimasukkan ke dalam tabung reaksi kemudian ditambahkan 0,2 mg serbuk $\mathrm{Mg}$ dan 3 tetes $\mathrm{HCl}$ pekat, kemudian dipanaskan pada suhu $105 \mathrm{oC}$. Jika terbentuk larutan berwarna merah, kuning atau jingga, maka ekstrak positif mengandung flavonoid [6].

\section{Uji Saponin}

Sebanyak $1 \mathrm{~mL}$ ekstrak dimasukkan ke dalam tabung reaksi kemudian ditambahkan $1 \mathrm{~mL}$ aquadest hangat kemudian digojog kuat selama \pm 1 menit. Jika terbentuk buih yang stabil, maka ekstrak positif mengandung saponin [6].

\section{Uji Tannin}

Sebanyak $1 \mathrm{~mL}$ ekstrak dimasukkan ke dalam tabung reaksi kemudianditambahkan $1 \mathrm{~mL} \quad \mathrm{FeCl}_{3} 1 \%$. Jika terbentuk larutan berwarna hijau kehitaman, maka ekstrak positif mengandung tanin [6].

\subsection{Formulasi Sabun Cair}

Formulasi sabun cair dibuat ekstrak etanol kulit buah salak pondoh diformulasikan dengan memodifikasi berdasarkan penelitian Agustina, dkk [7].

Tabel 1. Rancangan formula sabun cair

\begin{tabular}{lcl}
\hline \multicolumn{1}{c}{ Nama bahan } & $\begin{array}{c}\text { Konsetrasi } \\
\text { Bahan }\end{array}$ & Kegunaan \\
\hline Ekstrak kulit buah salak & $1 \%$ & Antioksidan \\
Carbopol 940 & $6 \%$ & Pengental \\
KOH & $0,15 \%$ & Basa penetral \\
Cocamido propil betain & $5 \%$ & Soft Surfaktan \\
SLS & $4 \%$ & Surfaktan \\
EDTA & $0,1 \%$ & Pengkhelat \\
Parfum & $\mathrm{q} . \mathrm{s}$ & Pengaroma \\
Akuades & ad $100 \mathrm{ml}$ & Pelarut \\
\hline
\end{tabular}

Semua bahan yang telah ditimbang dan alat yang akan digunakan disiapkan terlebih dahulu. Pembuatan diawali dengan mencampurkan SLS, Cocoaminido propyl betaine dan EDTA tambahkan sedikit aquadese diaduk hingga homogen, diamkan hingga busa menghilang, Pada wadah lain Carbopol secara perlahan-lahan didispersikan ke dalam aquades yang telah dipanaskan hingga suhu $70^{\circ} \mathrm{C}$ dan diaduk hingga terbentuk dispersi yang homogen. $\mathrm{KOH}$ sebagai penetral karbopol dilarutkan dengan aquades dan ditambahkan ke dalam dispersi karbopol, kemudian digabungkan dengan campuran SLS dan diaduk hingga homogen tambahkan pewarna dan pengaroma sebagai basis sabun. Selanjutnya masukkan ekstrak kulit salak, diaduk hingga homogen ditambahkan dengan aquades hingga volumenya $100 \mathrm{~mL}$, dimasukkan ke dalam pot wadah bersih yang telah disiapkan.

\subsection{Evaluasi Sediaan sabun cair}

Uji Organoleptik

Dimaksudkan untuk melihat penampakan atau tampilan fisik suatu sediaan yang meliputi bentuk, warna dan bau [8].

\section{Uji pH}

Uji derajat keasaman menggunakan $\mathrm{pH}$ meter. Alat $\mathrm{pH}$ meter dikalibrasi dengan larutan buffer setiap akan dilakukan pengukuran. Elektroda yang telah dibersihkan dicelupkan kedalam sampel yang akan diperiksa. Nilai $\mathrm{pH}$ pada skala $\mathrm{pH}$ meter dicatat [9].

\section{Pengujian Stabilitas Busa}

Sebanyak $1 \mathrm{~mL}$ sampel dimasukkan ke dalam tabung reaksi, kemudian ditambahkan air sebanyak $9 \mathrm{~mL}$. Diaduk hingga larut kemudian dikocok selama 20 detik, diukur tinggi busa yang terbentuk. Didiamkan selama 5 menit, diukur kembali tinggi busanya. Hitung stabilitas busa dengan rumus sebagai berikut [7],

$$
\text { Stabilitas busa } \%=\frac{\text { tinggi busa akhir }}{\text { tinggi busa awal }} \times 100 \%
$$

\section{Pengujian Viskositas}

Pengukuran dilakukan dengan alat viskometer Brookfield LV dengan spindle nomor 4. Kekentalan larutan diukur pada kecepatan pengadukan $30 \mathrm{rpm}$ dengan faktor koreksi adalah 200 . Hasil yang terbaca pada alat dikalikan dengan faktor koreksi [10].

\section{Hasil dan Pembahasan}

\subsection{Skrining Fitokimia}

Skrining fitokimia bertujuan untuk memberikan gambaran tentang golongan senyawa yang terkandung dalam tanaman yang sedang diteliti. Skrining fitokimia dilakukan dengan metode tabung, melihat reaksi pengujian warna dengan menggunakan suatu pereaksi warna [6]. Tabel 2 memperlihatkan hasil skrining fitokimia pada ekstrak kulit buah salak pondoh

Tabel 2. Hasil uji skrining fitokimia ekstrak kulit buah salak pondoh

\begin{tabular}{lcc}
\multicolumn{1}{c}{ Reagen } & Perubahan & Kesimpulan \\
\hline $\begin{array}{l}\text { Ekstrak }+ \text { serbuk } \\
\mathrm{Mg}+\mathrm{HCl} \text { pekat }\end{array}$ & Kekuningan & Positif Flavonoid \\
\hline $\begin{array}{l}\text { Ekstrak }+ \\
\text { aquadest hangat } \\
\text { kemudian } \\
\text { digojog }\end{array}$ & Terbentuk Buih & Positif Saponin \\
\hline $\begin{array}{l}\text { Ekstrak }+\mathrm{FeCl}_{3} \\
1 \%\end{array}$ & Hijau kehitaman & Positif Tanin \\
\hline $\begin{array}{l}\text { Ekstrak }+ \\
\text { pereaksi } \\
\text { Dragendorff }\end{array}$ & $\begin{array}{c}\text { Endapan merah } \\
\text { bata }\end{array}$ & Positif Alkaloid \\
\hline
\end{tabular}


Penambahan $\mathrm{Mg}$ dan $\mathrm{HCl}$ pekat dalam metode identifikasi flavonoid berfungsi untuk mereduksi inti benzopiron yang terdapat pada struktur flavanoid sehingga terjadi perubahan warna kuning akibat pembentukan garam flavilium yang merupakan ciri adanya flavonoid [11].

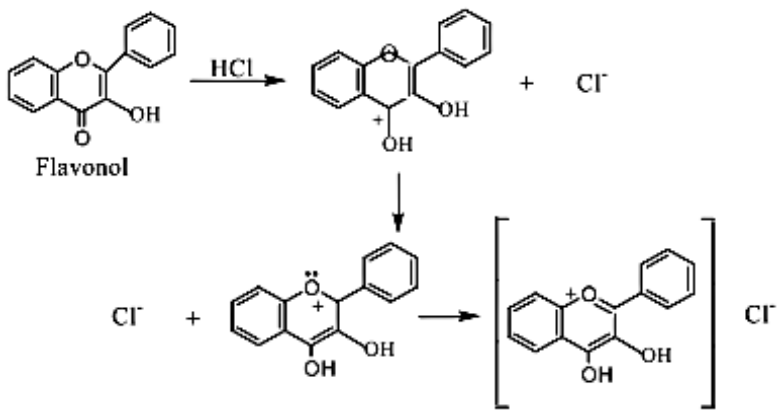

Gambar 1. Mekanisme pembentukan garam flavium [11]

Kandungan saponin dalam ekstrak etanol kulit buah salak pondoh ditandai dengan terbentuknya buih yang stabil yang menunjukkan adanya hidrolisis glikosida menjadi glukosa dan senyawa lainnya dengan mekanisme reaksi yang ditunjukkan pada Gambar 2 [12].

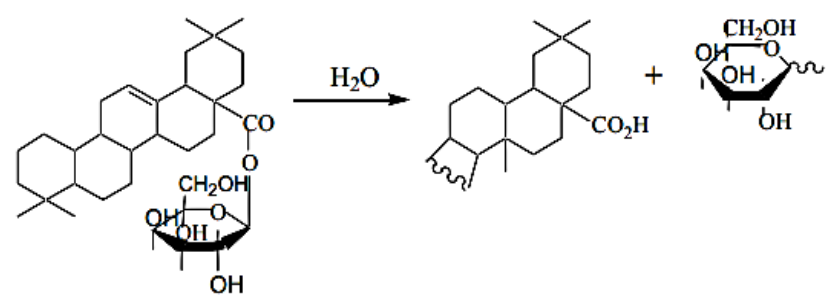

Saponin

Aglikon

Gukosa

Gambar 2. Reaksi hidrolisis saponin dalam air [12].

Pengujian tanin dilakukan dengan melakukan penambahan $\mathrm{FeCl}_{3} 1 \%$ yang akan menimbulkan warna biru tua, biru kehitaman atau hitam kehijauan. Menurut Sangi dkk [13], perubahan warna terjadi pada saat penambahan $\mathrm{FeCl}_{3}$ karena adanya gugus hidroksil yang ada pada senyawa tanin.

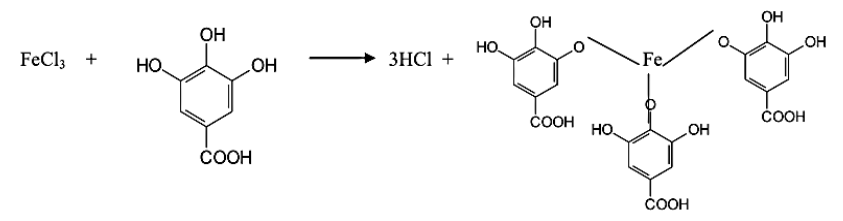

Gambar 2. Reaksi antara senyawa tannin dan $\mathrm{FeCl}_{3}$ [13].

Terbentuknya warna hitam pada ekstrak setelah ditambahkan $\mathrm{FeCl}_{3} 1 \%$ karena tanin akan bereaksi dengan ion $\mathrm{Fe}^{3+}$ membentuk senyawa kompleks. Pada uji tanin, ekstrak kulit buah salak pondoh menunjukkan hasil positif yang ditandai dengan terbentuknya warna hijau kehitaman pada saat pengujian [14].

Pada uji alkaloid, sampel berupa ekstrak etanol 96\% kulit buah salak ditambahkan dengan pereaksi Dragendorff sebanyak 3 tetes. Hasil positif uji alkaloid ditandai dengan terbentuknya endapan kuning hingga merah bata atau oranye.

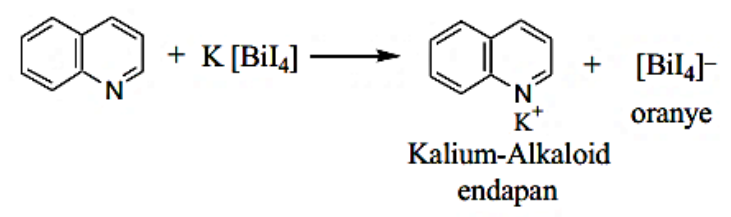

Gambar 3. Reaksi pembentukan endapan dalam pengujian alkaloid [12].

Mekanisme reaksi terjadinya perubahan warna merah bata atau oranye ini disebabkan oleh ikatan senyawa kalium tetraiodobismutat dalam pereaksi Dragendorff dengan alkaloid sehingga membentuk endapan kalium-alkaloid dan tetraidobismutat [12].

\subsection{Uji Sifat Fisik Sediaan Sabun Cair}

Beberapa pengujian diantaranya uji organoleptik, uji $\mathrm{pH}$, uji kestabilan busa, dan uji viskositas. Pengujian ini bertujuan untuk mengetahui mutu dari sediaan sabun cair apakah sesuai atau tidak dengan standar sabun cair yang telah ditetapkan oleh SNI [15].

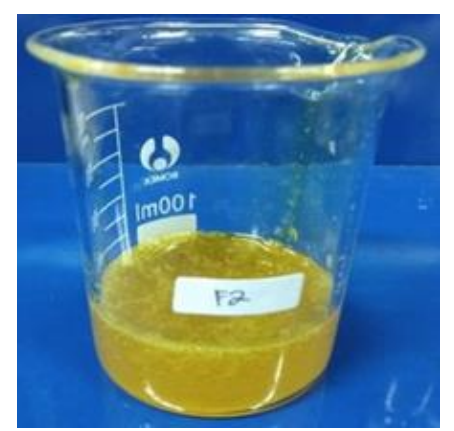

Gambar 3. Sediaan sabun cair ekstrak etanol kulit buah salak

Uji organoleptik dilakukan dengan melihat tampilan fisik suatu sediaan yang meliputi bentuk, warna dan bau. Standar untuk uji organoleptik sabun cair yang ditetapkan SNI, yaitu berbentuk cair, serta memiliki bau dan warna yang khas. Bentuk dari sabun cair yang dihasilkan pada penelitian yaitu berbentuk cair, bau rose, dan berwarna kuning kecoklatan. Terdapat bau rose karena penggunaan pengaroma rose untuk memberi aroma yang harum pada sabun cair serta menutupi bau khas dari ekstrak kulit buah salak. Sabun yang dihasilkan berwarna kuning kecoklatan, dimana warna coklat berasal dari ekstrak dengan penambahan pewarna kuning untuk menambah nilai estetika dari segi penampilan sabun cair. Berdasarkan hasil yang diperoleh, sabun cair yang dihasilkan sesuai dengan standar yang ditetapkan SNI [15].

Uji pH dimaksudkan untuk melihat derajat keasaman sabun cair, karena sabun cair kontak langsung dengan kulit dan dapat menimbulkan masalah apabila pH-nya tidak sesuai dengan $\mathrm{pH}$ kulit [9]. Standar dari SNI untuk $\mathrm{pH}$ sabun cair yang diperbolehkan yaitu antara 8-11. Dari hasil pengujian diperoleh $\mathrm{pH} 10,46$. Hasil menunjukkan sediaan memenuhi standar. 
Tabel 2. Pengujian sifat fisik sabun cair

\begin{tabular}{lcc}
\hline Jenis Pengujian & Hasil & Standar \\
\hline Uji organoleptik & $\begin{array}{l}\text { Bentuk cair, berwarna } \\
\text { kuning kecoklatan, } \\
\text { aroma rose }\end{array}$ & $\begin{array}{l}\text { Cair, warna } \\
\text { dan bau khas }\end{array}$ \\
\hline Uji pH & 10,46 & $8-11$ \\
\hline Uji Viskositas & $600 \mathrm{cPs}$ & $400-4000 \mathrm{cPs}$ \\
\hline $\begin{array}{l}\text { Uji Kestabilan } \\
\text { busa }\end{array}$ & $85 \%$ & $60-90 \%$ \\
\hline
\end{tabular}

Salah satu daya tarik sabun adalah kandungan busanya. Stabilitas busa dinyatakan sebagai ketahanan suatu gelembung untuk mempertahankan ukuran atau pecahnya lapisan film dari gelembung [16]. Berdasarkan standar kestabilan busa yang baik yaitu berkisar 60-90\%. Hasil evaluasi menunjukkan bahwa kestabilan busa $85 \%$ yaitu memiliki stabilitas yang baik [15].

Uji viskositas bertujuan untuk melihat kekentalan dari sediaan, yang berpengaruh dengan kemudahan tuang saat penggunaan. Nilai viskositas berdasarkan standar SNI sabun mandi cair yaitu 400-4000 cPs, dimana sabun cair yang memiliki viskositasnya $600 \mathrm{cP}$ dan memenuhi standar SNI [15].

\section{Kesimpulan}

Hasil skrining fitokimia menunjukkan bahwa kandungan metabolit sekunder yang terdapat dalam ekstark etanol 96\% kulit buah salak pondoh (Salacca zalacca (Gaert.) Voss.) adalah flavonoid, saponin, tanin dan alkaloid. Ekstrak tersebut dapat diformulasikan dalam sediaan sabun cair dengan karakteristik konsistensi cair, berwarna kuning kecoklatan, aroma rose. Nilai $\mathrm{pH}$ adalah 10,46; viskositas (kekentalan) yaitu $600 \mathrm{cPs}$ serta stabilitas busa yang mencapai $85 \%$

\section{Ucapan Terima Kasih}

Terimakasih penulis kepada oleh Universitas Halu Oleo (UHO) atas pendanaan penelitian ini melalui program Penelitian Dosen Pemula dalam Hibah Mandiri, Laboratorium Fakultas Farmasi UHO, dan Laboratorium Terpadu Institut Teknologi dan Kesehatan Avicenna.

\section{Daftar Pustaka}

1. Suryani S, Nafisah A, Mana'an S. Optimasi Formula Gel Antioksidan Ekstrak Etanol Buah Bligo (Benincasa hispida) dengan Metode Simplex Lattice Design (SLD), Jurnal
Farmasi Galenika, 2017, 3(2);57.

2. Purwaningsih S, Salamah E, Budiarti TA, Formulasi Skin Lotion dengan Penambahan Karagenan dan Antioksidan Alami dari Rhizophora mucronata Lamk, Akuatika, 2014, V(1);55-62.

3. Priyanto E, Mar M, Potensi Buah Salak: Sebagai Suplemen Obat dan Pangan. Muhammadiyah University Press; 2018.

4. Fauzi MR, Penghambatan $\alpha$-glukosidase, kadar fenolik dan flavonoid total ekstrak kulit dan daging buah salak beberapa varietas, Skripsi, Bogor: Institut Pertanian Bogor, 2016.

5. Laksana KP, Oktavillariantika AAIAS, Pratiwi NLPA, Wijayanti NPAD, Yustiantara PS, Optimasi Konsentrasi HPMC Terhadap Mutu Fisik Sediaan Sabun Cair Menthol. Jurnal Farmasi Udayana, 2017, 6(1);1-22.

6. Harborne JB, Metode Fitokimia: Penuntun cara modern menganalisis Tumbuhan, ditejemahkan oleh Kosasih Padmawinata dan Iwang Soediro, Bandung: Penerbit ITB, 1987.

7. Agustina L, Yulianti M, Shoviantari F, Sabban IF, Formulasi dan Evaluasi Sabun Mandi Cair dengan Ekstrak Tomat (Solanum lycopersicum L.) sebagai Antioksidan, Jurnal Wiyata Penelitian Sains dan Kesehatan, 2018, 4(2);104-10.

8. Kasenda JC, Yamlean PVY, Lolo WA, Formulasi dan Pengujian Aktivitas Antibakteri Sabun Cair Ekstrak Etanol Daun Ekor Kucing (Acalypha hispida Burm . F ) Terhadap Pertumbuhan Bakteri Staphylococcus aureus, Pharmacon: Jurnal Ilmiah Farmasi, 2016, 5(3);40-7.

9. Sari R, Ferdinan A, Antibacterial activity assay of the liquid soap from the extract of Aloe vera leaf peel. Pharm Sci Res., 2017, 4(3);111-20.

10. Nauli AP, Darmanto YS, Susanto E, Karakteristik Sabun Cair Dengan Penambahan Kolagen Ikan Air Laut Yang Berbeda. Jurnal Pengolahan dan Bioteknologi Hasil Perikanan, 2015, 4(4);1-6.

11. Achmad SA. Kimia Organik Bahan Alam, Jakrta: Penerbit Karunika Universitas Terbuka, 1986:65-73.

12. Marliana SD, Suryanti V, Suyono, Skrining Fitokimia dan Analisis Kromatografi Lapis Tipis Komponen Kimia Buah Labu Siam (Sechium edule Jacq. Swartz.) dalam Ekstrak Etanol, Biofarmasi, 2005, 3(1);26-31.

13. Sangi MS, Momuat LI, Kumaunang M, Uji Toksisitas dan Skrining Fitokimia Tepung Gabah Pelepah Aren (Arenga pinnata), Jurnal Ilmiah Sains, 2012, 12(2);127.

14. Ryanata E, Penentuan Jenis Tanin dan Penetapan Kadar Tanin dari Kulit Buah Pisang Masak (Musa paradisiaca L.) Secara Spektrofotometri dan Permanganometri, Jurnal Ilmiah Mahasiswa Universitas Surabaya, 2014, 4(1);1-16.

15. Standar Nasional Indonesia Tentang Sabun Mandi Cair. SNI 06-4085-1996. Jakarta; 1996.

16. Pradipto M, Pemanfaatan minyak jarak pagar (Jatropa curcas L) sebagai bahan dasar sabun mandi, Skripsi, Bogor: Fakultas Teknologi Pertanian Institut Pertanian Bogor, 2009. 